\title{
Effect of Crude Protein Level and Refeeding Method of Postmolt Diet on Performance and Egg Quality in Layers after Forced Molting
}

\author{
Yoshinori Fukuma ${ }^{1,2}$ and Teru IshiBashi ${ }^{1}$ \\ 'Animal Nutrition, Graduate School of Science and Technology, \\ Niigata University, Niigata-shi 950-21 \\ ${ }^{2}$ Reseach Center, Nihon Nosan Kogyo, Takura, Tsukuba-shi 300-33
}

\begin{abstract}
Effect of crude protein (CP) level and refeeding method of the postmolt diet on performance and egg quality in layers after forced molting was studied using 1,000 Single Comb White Leghorn layers. For a control group, another 60 layers did not undergo forced molting and were fed a layer diet ( $2.85 \mathrm{kcal} \mathrm{ME} / \mathrm{g}$ and $17.3 \% \mathrm{CP}$ ).

Forced molting was carried out using only fasting and light control. Fasting was continued until the body weight (BW) of the layers decreased about $30 \%$. The layers were then divided into four groups : the first group was fed a low CP diet $(2.57 \mathrm{kcal} \mathrm{ME} /$ $\mathrm{g}$ and $14.3 \% \mathrm{CP}$ ) ad libitum; the second group, a low $\mathrm{CP}$ diet on a restricted feeding schedule ; the third group, a high $\mathrm{CP} \operatorname{diet}(2.85 \mathrm{kcal} \mathrm{ME} / \mathrm{g}$ and $17.3 \% \mathrm{CP})$ ad libitum ; and the fourth group, a high $\mathrm{CP}$ diet on a restricted feeding schedule. In the restrictedfeeding groups, feed volume was increased gradually over 7 days, and then changed to $a d$ libitum. Each group was fed the postmolt diet till egg production reached $5 \%$, and then fed a layer diet.

The ad libitum-feeding groups had less accumulated mortalities than the restrictedfeeding groups during the refeeding period. The layers fed the high CP postmolt diet tended to produce heavier eggs than those fed the low CP diet. Neither CP level nor feeding method affected egg production, egg mass, feed intake, or egg quality after refeeding. The maximum improvement in egg quality (compared with the control group) occurred at week 12 of the fasting period : egg shell strength increased $1.23 \mathrm{~kg}$ / $\mathrm{cm}^{2}$; haugh units, 10.7 ; egg shell thickness, $0.038 \mathrm{~mm}$; and egg specific gravity, 0.006 .

These results indicate that an estimated CP content of lower than $14.3 \%$ in a postmolt diet is adequate for layers and that ad libitum-feeding is better than restricted-feeding for low mortalities.
\end{abstract}

(Jpn. Poult. Sci., 34 : 255-262, 1997)

Key words : postmolt diet, refeeding method, laying performance, egg quality

\section{Introduction}

Egg production rate and egg quality decline with advancing age of the laying hens (Cunningham et al., 1960 ; Roland, 1979 ; Bell and Adams, 1992). Attempts to counteract this decline include forced molting which can be induced either by manipulation of specific nutrition (ShIPPEe et al., 1979 ; Berry and BRAKe, 1987 ; Hussein et al., 1989 ; DICKERMAN and BAHR, 1989) or by fasting and photo-control (ANDREws et al., 1987 ; Hanzen and Yalcin, 1988). Studies have demonstrated its success (Roland and BaKer, 1982 ; Baker et al.,1983 ; Koelkebeck et al., 1992 ; Bell and Kuney, 1992).

The most popular forced molting method in Japan involves reducing the body

Received October 16, 1996 Accepted January 21, 1997 
weight (BW) of layers older than 70 weeks. In this method, the layers are first put on a fast until their BW decrease $30 \%$. The layers are then fed a low crude protein (CP) diet until their egg production reaches $5 \%$, and then switched to a layer diet. However, no reports support feeding layers low CP diets. The recent improved genetic performance of commercial layers may require higher $\mathrm{CP}$ and metabolizable energy (ME) levels in the postmolt diet than current levels. Although the amount of postmolt diet supplied to a layer is generally increased gradually during the refeeding period, but this is difficult to implement in modern automatic feeding systems. Therefore, $a d$ libitum refeeding during this post-fast period is preferable. Furthermore, because consumers demand high egg quality, the refeeding method and CP level must not have an adverse effect on egg quality.

The objective of this study is to clarify the effect of the dietary CP level and the refeeding method of the postmolt diet on laying performance, mortality, and egg quality in layers after a forced molting.

\section{Materials and Methods}

One thousand sixty Single Comb White Leghorn layers that were 66 weeks of age from our experimental farm were used in this experiment. On November 27, these birds had a $75 \%$ hen day egg production rate for 8 days prior and were housed in individual cages in a open house. Of these layers, 60 were used as the control group, which was fed the layer diet throughout the study and did not undergo forced molting. The other 1,000 layers were forced-molted under the feeding program and photocontrol (Fig. 1) described by ANDREws et al.(1987). After $24 \mathrm{hrs}$ lighting for 7 days, lighting time was shortened to $12 \mathrm{hrs}$ during the fasting period. After the fasting, 30 randomly selected hens were used as monitors ; They were weighed daily, and then fed the postmolt diet after they lost 30\% BW. From day 28 to 84, The lighting time was increased gradually to 16 hrs a day.

Table 1 shows the composition of the experimental diets, which were formulated using practical feedstuffs. We used a low $\mathrm{CP}$ diet that contained $2.57 \mathrm{kcal} \mathrm{ME} / \mathrm{g}, 14.3 \%$ $\mathrm{CP}$ and $2.5 \%$ calcium $(\mathrm{Ca})$; a high $\mathrm{CP}$ diet that contained $2.85 \mathrm{kcal} \mathrm{ME} / \mathrm{g}, 17.3 \% \mathrm{CP}$ and $1.9 \% \mathrm{Ca}$; and a layer diet that contained $2.85 \mathrm{kcal} \mathrm{ME} / \mathrm{g}, 17.3 \% \mathrm{CP}$ and $3.2 \% \mathrm{Ca}$.

At the end of the fasting period, the layers were divided into four groups of 250 each. During the refeeding period, the first group was fed the low $\mathrm{CP}$ diet ad libitum; the second group, the low $\mathrm{CP}$ diet on a restricted feeding schedule ; the third group, the

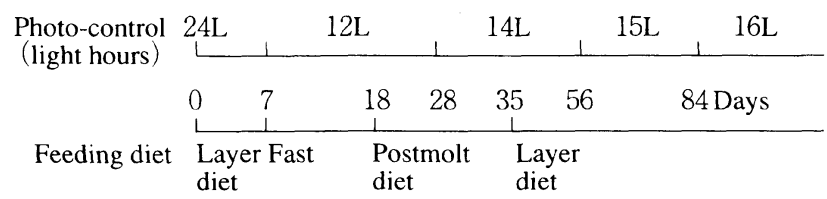

Fig. 1. Program of forced molting of layers at 66 weeks of age. Following $30 \%$ loss of body weight after fasting, postmolt diet was fed and then changed to layer diet after reaching $5 \%$ egg production. 
Table 1. Composition of postmolt and layer diets (\%)

\begin{tabular}{|c|c|c|c|}
\hline & \multicolumn{2}{|c|}{ Postmolt } & \multirow{2}{*}{ Layer } \\
\hline & low $\mathrm{CP}$ & high $\mathrm{CP}$ & \\
\hline Yellow corn & 32.9 & 53.65 & 51.0 \\
\hline Grain sorghum & 24.8 & 10.0 & 13.15 \\
\hline Raw rice bran & & 4.0 & 2.5 \\
\hline Defatted rice bran & 13.1 & 5.1 & \\
\hline Wheat bran & 5.0 & & \\
\hline Soybean meal ( $45 \% \mathrm{CP})$ & 4.1 & 15.7 & 3.9 \\
\hline Soybean meal $(48 \% \mathrm{CP})$ & & & 2.05 \\
\hline Rapeseed meal & 5.0 & 2.5 & 4.0 \\
\hline Sesame meal & & & 3.0 \\
\hline Safflower meal & 3.1 & & 0.5 \\
\hline Corn gluten feed & 2.8 & & 2.5 \\
\hline Corn gluten meal $(60 \% \mathrm{CP})$ & & & 4.45 \\
\hline Fish meal $(60 \% \mathrm{CP})$ & 1.0 & 2.0 & 1.0 \\
\hline Meat and born meal ( $45 \% \mathrm{CP})$ & 1.8 & 2.65 & 4.0 \\
\hline Animal fat & 0.5 & 0.5 & 1.0 \\
\hline Salt & 0.25 & 0.2 & 0.2 \\
\hline Calcium carbonate & 5.52 & 3.58 & 6.58 \\
\hline DL-methionine & 0.03 & 0.02 & 0.04 \\
\hline Paprika extract & & & 0.03 \\
\hline Mineral-Vitamin premix & 0.1 & 0.1 & 0.1 \\
\hline \multicolumn{4}{|l|}{ Calculated nutrients } \\
\hline Metabolizable energy $(\mathrm{kcal} / \mathrm{g})$ & 2.57 & 2.85 & 2.85 \\
\hline Crude protein & 14.3 & 17.3 & 17.3 \\
\hline Calcium & 2.5 & 1.9 & 3.2 \\
\hline Available phosphorus & 0.32 & 0.35 & 0.36 \\
\hline Methionine + Cystine & 0.56 & 0.65 & 0.65 \\
\hline
\end{tabular}

high CP diet ad libitum; and the fourth group, the high CP diet on a restricted feeding schedule. In restricted feeding, $20 \mathrm{~g}$ of postmolt diet was supplied to each layer on the first postmolt day and then increased $15 \mathrm{~g}$ every day thereafter. In ad libitum feeding, the postmolt diet was supplied ad libitum from the first postmolt day. When the hen day egg production rate reached $5 \%$ for a group, the group was fed the layer diet.

Egg production and egg weight were recorded daily and feed consumption biweekly. To determine the egg quality, from each group (including the control) we collected 30 eggs laid by the same hens, stored them in a refrigerator over night, and then weighed then. Egg specific gravity was measured using 11 kinds of copper sulfate liquid of various specific gravity, from 1.056 to 1.100 with the range of 0.004 . Egg shell strength, egg shell thickness and albumin height were measured using instruments made by Fujihira K.K.. The Haugh unit was calculated using the measured egg weight and albumin height with the equation by HAUGH (1937).

Statistical significance was determined by analysis of variance and the significance of difference between means was assayed by Duncan's new multiple range test 
(SAS Institute, 1985).

\section{Results}

It took 11 days for the fasting monitor hens to lose $30 \% \mathrm{BW}$ and 17 more days to reach a $5 \%$ egg production rate. Table 2 summarizes the performance of layers. In the forced molted hens, egg production rate decreased from $75.0 \%$ at 66 weeks to $0 \%$ at day 6 of the fasting period. After refeeding, the rate increased linearly, reached a maximum $82.7 \%$ at 78 weeks, and then decreased to a minimum $69.2 \%$ by 96 weeks. In the non-molted layers (control group), this rate decreased gradually from $75.0 \%$ at 66 weeks to $61.9 \%$ at 96 weeks. Neither CP level nor refeeding method affected egg production, egg weight, egg mass or feed intake.

Accumulated mortalities (Table 2) in the ad libitum feeding groups were lower than in the restricted feeding groups. Effect of $\mathrm{CP}$ level on mortality was small.

Maximum improvement in egg shell strength in the forced molt groups occurred at 78 weeks (Table 3 ), after which it declined again at the same rate as the non-molted

Table 2. Effect of dietary CP level and refeeding method on performance of layers

\begin{tabular}{|c|c|c|c|c|c|c|}
\hline & \multicolumn{2}{|c|}{ Low CP } & \multicolumn{2}{|c|}{ High $\mathrm{CP}$} & \multirow{2}{*}{$\begin{array}{l}\text { Non- } \\
\text { molted }\end{array}$} & \multirow{2}{*}{$\begin{array}{c}\text { Pooled } \\
\text { SEM }\end{array}$} \\
\hline & Ad libitum & Restricted & Ad libitum & Restricted & & \\
\hline Egg production ${ }^{1}(\%)$ & 70.6 & 69.6 & 67.1 & 69.3 & 68.0 & 1.56 \\
\hline Peak egg production $(\%)$ & 82.7 & 82.2 & 77.9 & 81.8 & - & \\
\hline Egg production at 96 weeks & 69.7 & 75.3 & 69.2 & 72.7 & 61.9 & \\
\hline Egg weight ${ }^{1}(g)$ & $67.9^{\mathrm{b}}$ & $68.1^{\mathrm{ab}}$ & $68.6^{\mathrm{ab}}$ & $67.8^{\mathrm{b}}$ & $69.1^{\mathrm{a}}$ & 0.13 \\
\hline Egg $\operatorname{mass}^{1}$ (g/layer/day) & 48.1 & 47.6 & 46.1 & 47.1 & 47.0 & 1.08 \\
\hline Feed intake ${ }^{2}$ (g/layer/day) & 119.1 & 120.2 & 119.1 & 119.2 & 120.9 & 0.87 \\
\hline \multicolumn{7}{|l|}{ Accumulated mortality $(\%)$} \\
\hline at 69 weeks & 0.35 & 2.25 & 0.69 & 1.03 & & \\
\hline at 96 weeks & 2.44 & 4.32 & 2.74 & 4.48 & & \\
\hline
\end{tabular}

${ }^{\mathrm{a}, \mathrm{b}}$ Means within a row with no common superscripts are significantly different.

${ }^{1}$ Calculated from 71 to 96 weeks of age.

${ }^{2}$ Calculated from 69 to 96 weeks of age.

Table 3. Effect of dietary CP level and refeeding method on egg shell strength $\left(\mathrm{kg} / \mathrm{cm}^{2}\right)$

\begin{tabular}{|c|c|c|c|c|c|c|}
\hline \multirow{2}{*}{$\begin{array}{c}\text { Age } \\
\text { (weeks) }\end{array}$} & \multicolumn{2}{|c|}{ Low CP } & \multicolumn{2}{|c|}{ High CP } & \multirow{2}{*}{ Non-molted } & \multirow{2}{*}{$\begin{array}{l}\text { Pooled } \\
\text { SEM }\end{array}$} \\
\hline & Ad libitum & Restricted & Ad libitum & Restricted & & \\
\hline 66 & $2.76^{\mathrm{ab}}$ & $2.72^{\mathrm{ab}}$ & $3.05^{\mathrm{a}}$ & $3.00^{\mathrm{ab}}$ & $2.67^{\mathrm{b}}$ & 0.06 \\
\hline 75 & $3.68^{\mathrm{a}}$ & $3.54^{\mathrm{a}}$ & $3.36^{\mathrm{a}}$ & $3.54^{\mathrm{a}}$ & $2.68^{b}$ & 0.06 \\
\hline 78 & $3.87^{\mathrm{a}}$ & $3.50^{\mathrm{a}}$ & $3.66^{\mathrm{a}}$ & $3.67^{\mathrm{a}}$ & $2.64^{\mathrm{b}}$ & 0.07 \\
\hline 80 & $3.51^{\mathrm{a}}$ & $3.26^{\mathrm{a}}$ & $3.46^{\mathrm{a}}$ & $3.62^{\mathrm{a}}$ & $2.53^{\mathrm{b}}$ & 0.06 \\
\hline 82 & $3.16^{\mathrm{a}}$ & $3.01^{\mathrm{a}}$ & $3.19^{\mathrm{a}}$ & $3.17^{\mathrm{a}}$ & $2.14^{\mathrm{b}}$ & 0.07 \\
\hline 84 & $3.21^{\mathrm{a}}$ & $3.08^{\mathrm{a}}$ & $3.07^{\mathrm{a}}$ & $3.20^{\mathrm{a}}$ & $2.31^{\mathrm{b}}$ & 0.07 \\
\hline 86 & $3.22^{\mathrm{ab}}$ & $2.94^{\mathrm{b}}$ & $3.06^{\mathrm{ab}}$ & $3.45^{\mathrm{a}}$ & $2.47^{\mathrm{c}}$ & 0.07 \\
\hline 90 & $2.84^{\mathrm{ab}}$ & $2.95^{\mathrm{ab}}$ & $3.25^{\mathrm{a}}$ & $3.01^{\mathrm{ab}}$ & $2.54^{\mathrm{b}}$ & 0.08 \\
\hline
\end{tabular}

${ }^{a, b}$ Means within a row with no common superscripts are significantly different. 
group. The egg shell strength improved a maximum $20 \%$ compared with the strength at 66 weeks, which was before the fasting period. Compared with the non-molted group, The egg shell strength increased by a maximum $1.23(3.87: 2.64) \mathrm{kg} / \mathrm{cm}^{2}$. Neither $\mathrm{CP}$ level nor refeeding method affected egg shell strength. Similar improvement

Table 4. Effect of dietary CP level and refeeding method on Haugh unit

\begin{tabular}{ccccccc}
\hline \multirow{2}{*}{$\begin{array}{c}\text { Age } \\
\text { (weeks) }\end{array}$} & \multicolumn{2}{c}{ Low CP } & \multicolumn{2}{c}{ High CP } & Non-molted & $\begin{array}{c}\text { Pooled } \\
\text { SEM }\end{array}$ \\
\cline { 2 - 3 } & Ad libitum & Restricted & Ad libitum & Restricted & & \\
\hline 66 & $79.6^{\mathrm{ab}}$ & $76.7^{\mathrm{b}}$ & $80.7^{\mathrm{a}}$ & $79.4^{\mathrm{ab}}$ & $78.0^{\mathrm{ab}}$ & 0.6 \\
75 & $79.6^{\mathrm{b}}$ & $80.5^{\mathrm{ab}}$ & $81.2^{\mathrm{ab}}$ & $82.8^{\mathrm{a}}$ & $70.5^{\mathrm{c}}$ & 0.7 \\
78 & $84.6^{\mathrm{a}}$ & $81.5^{\mathrm{b}}$ & $81.4^{\mathrm{b}}$ & $86.1^{\mathrm{a}}$ & $75.4^{\mathrm{c}}$ & 0.6 \\
82 & $78.9^{\mathrm{b}}$ & $79.0^{\mathrm{b}}$ & $82.3^{\mathrm{a}}$ & $79.8^{\mathrm{b}}$ & $71.4^{\mathrm{c}}$ & 0.6 \\
86 & $83.3^{\mathrm{ab}}$ & $82.0^{\mathrm{b}}$ & $85.6^{\mathrm{a}}$ & $83.0^{\mathrm{ab}}$ & $69.3^{\mathrm{c}}$ & 0.9 \\
90 & $82.1^{\mathrm{a}}$ & $79.4^{\mathrm{a}}$ & $82.3^{\mathrm{a}}$ & $82.1^{\mathrm{a}}$ & $68.0^{\mathrm{b}}$ & 0.9 \\
94 & $77.8^{\mathrm{a}}$ & $80.0^{\mathrm{a}}$ & $77.5^{\mathrm{a}}$ & $78.0^{\mathrm{a}}$ & $68.0^{\mathrm{b}}$ & 0.7 \\
99 & $78.2^{\mathrm{a}}$ & $72.9^{\mathrm{b}}$ & $78.1^{\mathrm{a}}$ & $75.1^{\mathrm{ab}}$ & $61.3^{\mathrm{c}}$ & 0.9 \\
\hline
\end{tabular}

${ }^{\mathrm{a}, \mathrm{b}}$ Means within a row with no common superscripts are significantly different.

Table 5. Effect of dietary CP level and refeeding method on egg shell thickness (mm)

\begin{tabular}{|c|c|c|c|c|c|c|}
\hline \multirow{2}{*}{$\begin{array}{c}\text { Age } \\
\text { (weeks) }\end{array}$} & \multicolumn{2}{|c|}{ Low CP } & \multicolumn{2}{|c|}{ High CP } & \multirow{2}{*}{ Non-molted } & \multirow{2}{*}{$\begin{array}{l}\text { Pooled } \\
\text { SEM }\end{array}$} \\
\hline & Ad libitum & Restricted & Ad libitum & Restricted & & \\
\hline 66 & 0.371 & 0.374 & 0.379 & 0.371 & 0.382 & 0.002 \\
\hline 75 & $0.398^{\mathrm{a}}$ & $0.393^{\mathrm{ab}}$ & $0.388^{\mathrm{ab}}$ & $0.401^{\mathrm{a}}$ & $0.383^{\mathrm{b}}$ & 0.002 \\
\hline 78 & $0.395^{\mathrm{a}}$ & $0.379^{\mathrm{b}}$ & $0.405^{\mathrm{a}}$ & $0.406^{\mathrm{a}}$ & $0.368^{b}$ & 0.002 \\
\hline 82 & $0.372^{\mathrm{a}}$ & $0.372^{\mathrm{a}}$ & $0.366^{\mathrm{ab}}$ & $0.373^{\mathrm{a}}$ & $0.355^{\mathrm{b}}$ & 0.002 \\
\hline 86 & $0.375^{\mathrm{a}}$ & $0.371^{\mathrm{ab}}$ & $0.380^{\mathrm{a}}$ & $0.380^{\mathrm{a}}$ & $0.360^{\mathrm{b}}$ & 0.002 \\
\hline 90 & $0.375^{\mathrm{a}}$ & $0.359^{\mathrm{b}}$ & $0.362^{\mathrm{ab}}$ & $0.364^{\mathrm{ab}}$ & $0.366^{\mathrm{b}}$ & 0.002 \\
\hline 94 & 0.358 & 0.358 & 0.362 & 0.357 & 0.354 & 0.002 \\
\hline 99 & 0.362 & 0.357 & 0.357 & 0.355 & 0.355 & 0.003 \\
\hline
\end{tabular}

${ }^{a, b}$ Means within a row with no common superscripts are significantly different.

Table 6. Effect of dietary CP level and refeeding method on egg specific gravity

\begin{tabular}{|c|c|c|c|c|c|c|}
\hline \multirow{2}{*}{$\begin{array}{c}\text { Age } \\
\text { (weeks) }\end{array}$} & \multicolumn{2}{|c|}{ Low CP } & \multicolumn{2}{|c|}{ High CP } & \multirow{2}{*}{ Non-molted } & \multirow{2}{*}{$\begin{array}{l}\text { Pooled } \\
\text { SEM }\end{array}$} \\
\hline & Ad libitum & Restricted & Ad libitum & Restricted & & \\
\hline 66 & 1.079 & 1.079 & 1.081 & 1.079 & 1.080 & 0.0004 \\
\hline 75 & $1.086^{\mathrm{a}}$ & $1.086^{\mathrm{a}}$ & $1.083^{\mathrm{b}}$ & $1.085^{\mathrm{ab}}$ & $1.081^{\mathrm{b}}$ & 0.0004 \\
\hline 78 & $1.086^{\mathrm{a}}$ & $1.084^{\mathrm{b}}$ & $1.086^{\mathrm{ab}}$ & $1.086^{\mathrm{a}}$ & $1.080^{c}$ & 0.0004 \\
\hline 82 & $1.083^{\mathrm{a}}$ & $1.083^{\mathrm{a}}$ & $1.082^{\mathrm{a}}$ & $1.083^{\mathrm{a}}$ & $1.077^{\mathrm{b}}$ & 0.0004 \\
\hline 86 & $1.083^{\mathrm{a}}$ & $1.082^{\mathrm{a}}$ & $1.081^{\mathrm{a}}$ & $1.082^{\mathrm{a}}$ & $1.077^{\mathrm{b}}$ & 0.0004 \\
\hline 90 & $1.082^{\mathrm{a}}$ & $1.080^{\mathrm{ab}}$ & $1.079^{\mathrm{b}}$ & $1.080^{\mathrm{ab}}$ & $1.078^{\mathrm{b}}$ & 0.0004 \\
\hline 94 & $1.079^{\mathrm{a}}$ & $1.078^{\mathrm{a}}$ & $1.078^{\mathrm{a}}$ & $1.078^{\mathrm{a}}$ & $1.074^{\mathrm{b}}$ & 0.0004 \\
\hline 99 & $1.080^{\mathrm{a}}$ & $1.078^{\mathrm{a}}$ & $1.078^{\mathrm{ab}}$ & $1.078^{\mathrm{a}}$ & $1.075^{b}$ & 0.0005 \\
\hline
\end{tabular}

${ }^{\mathrm{a}, \mathrm{b}}$ Means within a row with no common superscripts are significantly different. 
were also seen in the Haugh unit, egg shell thickness and egg specific gravity (Tables 4,5 and 6 , respectively). Compared with the values at 66 weeks (prior to fasting), the maximum improvement occurred at 78 weeks : the Haugh unit increased $5.4 \%$, the egg shell thickness $5.7 \%$, and the egg specific gravity $0.5 \%$. Compared with the maximum value for the control group, the Haugh unit for the molted groups increased by a maximum $10.7(86.1: 75.4)$, the egg shell thickness by $0.038(0.406: 0.368) \mathrm{mm}$, the egg specific gravity by $0.006(1.086: 1.080)$. Neither CP level nor refeeding method affected these properties.

\section{Discussion}

ANDREws et al. (1987) compared a 16\% CP diet and a cracked corn diet, and BELL and KunEy (1992) compared a $16.7 \% \mathrm{CP}$ diet and a milo diet. Both reported that the difference in dietary $\mathrm{CP}$ did not affect performance and egg quality. Our findings here are similar : no difference between the $14.3 \%$ and $17.3 \% \mathrm{CP}$ diets as a postmolt diet. This means that $14.3 \% \mathrm{CP}$ content is adequate in a postmolt diet.

The mortality for the ad libitum feeding groups during the refeeding period was lower than that for the restricted feeding groups. In our experiments, the hens were housed in individual cages. If several hens had been housed in a single cage, the mortality due to fasting would have been even higher, because the stronger hens would have eaten all the food during the restricted feeding period, thus forcing the weaker hens to continue their fast.

In Japan, egg shell strength and Haugh unit, and not egg specific gravity, are usually used as a measure of egg quality. Recently, a standard value of egg strength and Haugh unit are used by large stores. Although Improvement in egg specific gravity was lowest among the properties measured in our study, the variance was the smallest. This means that egg specific gravity may be better than egg shell strength and Haugh unit as an index of egg quality.

Table 7. Coefficient of correlation by linear regression between egg weight (x) and egg strength $(y)$ in forced-molted or non-molted layers

\begin{tabular}{|c|c|c|c|c|}
\hline \multirow{2}{*}{ Age (weeks) } & \multicolumn{2}{|c|}{ Forced-molted } & \multicolumn{2}{|c|}{ Non-molted } \\
\hline & Number & Coefficient & Number & Coefficient \\
\hline 66 & 116 & 0.05 & 30 & -0.02 \\
\hline 75 & 120 & 0.05 & 29 & 0.07 \\
\hline 78 & 119 & 0.10 & 29 & -0.14 \\
\hline 80 & 120 & 0.06 & 30 & -0.17 \\
\hline 82 & 120 & 0.12 & 30 & -0.06 \\
\hline 84 & 119 & -0.09 & 29 & 0.18 \\
\hline 86 & 120 & -0.06 & 29 & 0.02 \\
\hline 88 & 119 & -0.07 & 30 & 0.26 \\
\hline 90 & 119 & 0.02 & 24 & -0.26 \\
\hline 92 & 120 & -0.04 & 30 & -0.02 \\
\hline 94 & 120 & -0.05 & 28 & 0.22 \\
\hline 96 & 120 & -0.18 & 27 & 0.05 \\
\hline
\end{tabular}


It is commonly believed that big eggs generally have low egg shell strength, because bigger, eggs have thinner shells. We found however that the coefficient of correlation between egg weight and egg shell strength was very low for layers at the same age (Table 7). This indicates that egg weight does not affect egg shell strength and therefore controlling the egg weight is not effective in improving the egg shell strength.

\section{References}

ANDREws D.K., W.D. BerRy and J. BRAKE (1987) Effect of lighting program and nutrition on reproductive performance of molted single comb white leghorn hens. Poultry Science, 66 : 1298-1305.

BAKER, M., J. BRAKE and G.R. MCDANIEL (1983) The relationship between body weight loss during an induced molt and postmolt egg production, egg weight, and shell quality in caged layers. Poultry Science, $62:$ 409-413.

Bell, D.D. and C.J. Adams (1992) First and second cycle egg production characteristics in commercial table egg flocks. Poultry Science, $71: 448-459$.

BeLL, D.D. and D.R. KunEY (1992) Effect of fasting and post-fast diets on performance in molted flocks. Journal of Applied Poultry Research, $1: 200-206$.

BERRY, W,D. and J. BRAKE (1987) Postmolt performance of laying hens molted by high dietary zinc, low dietary sodium, and fasting : Egg production and eggshell quality. Poultry Science, 66 : 218-226.

Cunningham, F.E., O.J. CotTerill and E.M. Funk (1960) The effect of season and age of birds. 1. On egg size, quality and yield. Poultry Science, $39: 289-299$.

DiCKERMAN, R.W. and J.M. BAHR (1989) Molt induced by gonadotropin-releasing hormone agonist as a model for studying endocrine mechanisms of molting in laying hens. Poultry Science, $\mathbf{5 8}$ : 949-954.

HAZAN A. and S. YALCIN (1988) Effect of body weight loss and feeding regimen on the performance of moulted breeder layers. British Poultry Science, 29 : 513-520.

Haugh, R.R. (1937) The haugh unit for measuring egg quality. US Egg Poultry Magazine, 43 : 522573.

Hussein, A.S., A.H. CANTOR and T.H. Johnson (1989) Comparison of the use of dietary aluminum with the use of feed restriction for force-molting laying hens. Poultry Science, 68 : 891-896.

Koelkebeck, K.W., C.M. Parsons, R.W. Leeper and J. Moshtaghian (1992) Effect of duration of fasting on postmolt laying hen performance. Poultry Science, $71: 434-439$.

Roland, D.A. SR. (1979) Factors influencing shell quality of aging hens. Poultry Science, 58 : 774777.

ROLAND, D.A. SR. and J. BRAKE (1982) Influence of premolt production on postmolt performance with explanation for improvement in egg production due to force molting. Poultry Science, 61:2473-2481.

SAS Institute (1985) SAS User's Guide : Statistics, 5th ed., Cary, NC., U.S.A.

Shippee, R.L., P.E. Stake, U. Koenn, J.L. Lambert and R.W. Simmons (1979) High dietary zinc or magnesium as forced-resting agents for laying hens. Poultry Science, $58: 949-954$. 


\title{
換羽後飼料の粗蛋白質レベルおよび再給餌方法の 産卵成績および卵質への影響
}

\author{
福間義教 1,2 石橋 晃 ${ }^{1}$ \\ 1 新潟大学大学院自然科学研究科, 新潟市五十嵐二の町 8050, 950-21 \\ ${ }^{2}$ 日本農産工業株式会社中央研究所, つくば市田倉 5246，300-33
}

\begin{abstract}
飼料の粗蛋白質 (CP) レベルおよび再給餌方法の違い が強制換羽 (強換) 後の産卵成績および卵質に与える影 響を 66 週龄の白レグ系産卵鶏 1,060 羽を用いて, 60 羽 は強換せず対照区として調べた。

強換は点灯管理と絶食で実施し, 絶食は体重が $30 \%$ 減少するまで継続した。その後は 250 羽ずつの 4 区にわ け, ME $2.57 \mathrm{kcal} / \mathrm{g}-\mathrm{CP} 14.3 \%$ ME $2.85 \mathrm{kcal} / \mathrm{g}-\mathrm{CP}$ $17.3 \%$ の飼料を自由攝取または 7 日間の制限給餉後自由 摂取とした。換羽後飼料は産卵率が $5 \%$ に達するまで給 与し, その後は ME $2.85 \mathrm{kcal} / \mathrm{g}-\mathrm{CP} 17.3 \%$ の成鷄用飼料 を給与した。
\end{abstract}

累積敝死率は, 再給餉を飽食させた方が少なかった。
卵重は高蛋白質飼料を再給䭒した方が重い傾向にあっ た。しかし, 再給餉飼料や給餉方法の違いは, 産卵率, 日卵量，摂取量，卵質には影響を与えなかった。卵質は 絶食開始後約 12 週間目に改善率が最大となり, その後 漸減した。強換をしない区と比較すると, 卵款強度, 八 ウ・ユニット，卵殻厚および比重はそれぞれ最大で 1.23 $\mathrm{kg} / \mathrm{cm}^{2}, 10.7,0.038 \mathrm{~mm}, 0.006$ 優れていた。 以上の結果から換羽後飼料の CP は $14.3 \%$ 以下で. 再 給与は飽食の方が良いことが示唆された。

（家离会誌, 34:255-262, 1997) キーワード : 換羽後飼料, 再給餌方法, 産卵成績, 卵質 